\title{
牛血液型検查の実際と乞の応用（II）
}

\author{
阿 部 恒 夫*
}

\section{III. 牛血液蛋白質型の検査法}

抗血清による赤血球の型の分類（狭義の血液型）のほ かに, 血球や血清中に含まれる各種の蛋白質や酵素類を 電気泳動によって分離し, その遺伝的個体差を検出する ことができる, 例えば, 牛血清アルブミンは濾紙電気泳 動では 1 本のバンドとしてみとめられ個体差はみられな いが, 分離能のすぐれた殿粉ゲル電気泳動を行ならと個 体により 1 ～ 2 本のバンドに分かれ 3 型に分類すること ができる.このように同一種の集団内において，同一機 能を有する蛋白質に遺伝的変異がみられることを蛋白質 の多型現象（protein polymorphism）といら. 蛋白質の 多型は血液蛋白質にかぎらず乳蛋白質, 精液, 臓器にも みられる. そして酵素蛋白質の多型は，しばしばアイン ザイムと呼ばれる.

多型の検出のためには, 特殊な抗血清を必要としない ので各家畜において多くの多型が発見され，それらのう ちの幾つかは, 赤血球抗原型と同様に標識遺伝形質とし て親子鑑別その他に実際に利用されている. 表 5 には, わが国で実際に用いられている血液蛋白質と乳蛋白質の 多型を示した. 多型は通常は共優性遺伝子によって支配 されているので， $\mathrm{n}$ 個の対立遺伝子によって支配されて いる座位では $\mathrm{n}(\mathrm{n}+1) / 2$ 型の表現型あるいは遺伝子型 がある. 例えば牛血清トランスフェリン型は通常 4 つの 対立遺伝子 $\mathrm{Tf}^{\mathrm{A}}, \mathrm{Tf}^{\mathrm{D}_{1}}, \mathrm{Tf}^{\mathrm{D}_{2}}, \mathrm{Tf}^{\mathrm{E}}$ に支配され, その組
合せから $4(4+1) / 2=10$ 型の遺伝子型が存在する. 電気 泳動法としてはいろいろの方法があるが，蛋白質の分離 能の点ですぐれている殿粉ゲル電気泳動法が最も良く用 いられているので, 以下その実際について述べる.

\section{1. 殿粉ゲル電気泳動に必要な器具・試薬}

ゲル枠 : 緩衝液で加熱溶解した殿粉ゲルを注入し, 固 化するために用いるアクリル樹脂製のゲル枠打よび上ぶ た. 著者らは， $25 \times 12 \times 0.6 \mathrm{~cm}$ (血液用) および $20 \times 15$ $\times 0.2 \mathrm{~cm}$ (乳蛋白質用) の 2 種類のサイズのものを常用 している.

試料插入用カッター：固化したゲルに垂直に插入し， 試料を浸した滤紙片を挿入する切りこみをつける道具で ある. 薄い硬質ビニール板をカッターで切り抜き, 自分 で作ることができる，刃の大きさは濾紙片に合わせ，刃 の枚数は 10〜13 枚とする.

ゲルカッター：泳動後のゲルを水平に切るための道 具. ナイロン釣糸でもよい.

試料用慮紙片 : 東洋濾紙 No. 525 (厚手) あるいは No. 54 (薄手)を試料構の中と高さに合わせて切る. 通常 0.6 $\times 0.6 \mathrm{~cm}$ が用いられる.

泳動用直流発生装置: 出力, 定電圧 $0 \sim 1,500 \mathrm{~V}$, 定 電流 0〜80 $\mathrm{mA}$ 位のものでよい.

電極槽およびブリッジ硬質ビニール製 $20 \times 10 \times 4 \mathrm{~cm}$ で中仕切りのあるものがよい. ブリッジとしては濾紙を $3 \sim 4$ 枚重悋て用いるか, 厚さ $2 \sim 3 \mathrm{~cm}$ のビニールスポ

表 5 わが国において，電気泳動法により検査されている牛血液蛋白質型と乳蛋白質型

\begin{tabular}{|c|c|c|c|c|c|}
\hline & & システム記号 & タンパク質 & 遺伝子型数 & 対立遺伝子 \\
\hline \multirow{7}{*}{ 血 } & \multirow{7}{*}{ 液 } & \multirow{7}{*}{$\begin{array}{l}\text { 清 }\left\{\begin{array}{l}\text { Alb } \\
\text { Am } \\
\text { Alp } \\
\text { Cp }\end{array}\right. \\
\text { 球 }\left\{\begin{array}{l}\mathrm{CA} \\
\mathrm{Hb}\end{array}\right.\end{array}$} & Transferrin & 10 & $A_{1}, D_{1}, D_{2}, E$ \\
\hline & & & Albumin & 3 & A, B \\
\hline & & & Amylase & 6 & $A, B, C$ \\
\hline & & & Alkaline Phosphatase & 3 & $\mathrm{~A}, \mathrm{O}$ \\
\hline & & & Ceruloplasmin & 6 & $A, B, C$ \\
\hline & & & Carbonic Anhydrase & 3 & $\mathrm{~F}, \mathrm{~S}$ \\
\hline & & & Hemoglobin & 6 & $\mathrm{~A}, \mathrm{~B},(\mathrm{C})$ \\
\hline \multirow{5}{*}{\multicolumn{2}{|c|}{ 乳 }} & $\alpha_{s 1}-\mathrm{Cn}$ & $\alpha_{s 1}$-Casein & 10 & (A), B, C, (D) \\
\hline & & $\beta-\mathrm{Cn}$ & $\beta$-Casein & 6 & $\mathrm{~A}, \mathrm{~B}, \mathrm{C}$ \\
\hline & & $\kappa-\mathrm{Cn}$ & $\kappa$-Casein & 3 & A, B \\
\hline & & $\alpha-\mathrm{La}$ & $\alpha$-Lactalbumin & 3 & (A), B \\
\hline & & $\beta$-Lg & $\beta$-Lactoglobulin & 10 & $\mathrm{~A}, \mathrm{~B},(\mathrm{C}),(\mathrm{D})$ \\
\hline
\end{tabular}

（）は，稀な対立遺伝子

* 農林省畜産試験場（千葉市青葉町959） 


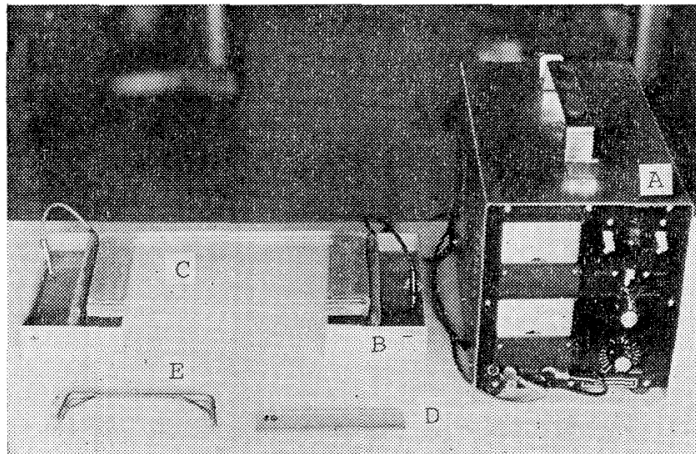

写真 2 殿粉ゲル電気泳動装置
A. 直流発生装置
B. 電極槽
C、ゲル枠
D. 試料插入用カッター
E. ゲルカッター

ンジが息い。

ナス型フラスコ : $1 l$ 容量のもので, 加水分解殿粉と 緩衝液を加えて

加熱しゲル化するために用いる．脱気用のガラス管をつ けたコルク栓をする。

真空ポンプまたはサッカー：ゲル中の気泡を除去する ために用いる。

保冷庫：泳動中のゲルの発熱を防止するために $5^{\circ} \mathrm{C}$ 前 後の薬用保冷庫か冷蔵庫内で泳動する。ゲル板上にガラ ス板をのせ，その上に冷谏したアイスノンをのせて泳動 しても良い結果が得られる。

加水分解殿粉：カナダ，コンノート製のものが良い. 染色液 : 蛋白染色用としては下記の組成のもの肴用い る.

$$
\begin{array}{ll}
\text { 脱イオン水 } & 400 \mathrm{ml} \\
\text { メチルアルコール } & 500 \mathrm{ml} \\
\text { 水酢酸 } & 100 \mathrm{ml} \\
\text { アミドブラック } 10 \mathrm{~B} & 125 \mathrm{mg} \\
\text { ニグロシン } & 250 \mathrm{mg}
\end{array}
$$

脱色液: $\begin{cases}\text { 脱イオン水 } & 500 \mathrm{~m} l \\ \text { メチルアルコール } & 500 \mathrm{~m} l \\ \text { 氷眽酸 } & 100 \mathrm{~m} l\end{cases}$

\section{緩衝液組成：(Tf・Am・CA 型用)}

ゲル用緩衝液 $\left\{\begin{array}{lll}\text { トリスアミノメタン } & 1.70 \mathrm{~g}(1.60 \mathrm{~g}) \\ \text { クエン酸 } & 0.84 \mathrm{~g}(1.00 \mathrm{~g}) \\ \text { 脱イオン水を加它て } 1 l \text { とする. } \\ \mathrm{pH} & 7.6 & (\mathrm{pH} 6.3)\end{array}\right.$ カッニ内の組成のものは, $\mathrm{pH}$ は 6.3 であり Tf 型の $\mathrm{D}_{1}$ と $\mathrm{D}_{2}$ の分離が極めて良い.

$$
\text { 電極用緩衝液 }\left\{\begin{array}{lc}
\text { ホウ酸 } & 18.56 \mathrm{~g} \\
\text { 苛性ソーダ } & 4.0 \mathrm{~g} \\
\text { 脱イオン水を加えて } 1 l \text { とする. } & \mathrm{pH} 8.6
\end{array}\right.
$$

講座

( $\mathrm{Hb}$ 型用)

電極用緩衙液

$\left\{\begin{array}{lc}\text { トリスアミノメタン } & 30.2 \mathrm{~g} \\ \mathrm{EDTA} & 3.0 \mathrm{~g} \\ \text { ホウ酸 } & 2.3 \mathrm{~g} \\ \text { 脱イオン水を加えて } 1 l \text { とする. }\end{array}\right.$

$\mathrm{pH} 8.6$

ゲル用緩衝液は，電極用緩衝液を脱イオン水で 5 倍に して用いる。

(Alb 型用)

電極用とゲル用緩衝液は，同じものを使用する。

$$
\left\{\begin{array}{lr}
\text { タエン酸 } & 0.84 \mathrm{~g} \\
\text { トリスアミノメタン } & 1.00 \mathrm{~g} \\
\text { 脱イオン水を加觉て } 1 l \text { とする. } & \mathrm{pH} 5.6
\end{array}\right.
$$

(Cp 型用)

$$
\text { ゲル用緩衝液 } \begin{cases}\text { トリスアミノメタン } & 8.67 \mathrm{~g} \\ \text { クェン酸 } & 1.33 \mathrm{~g} \\ \text { 脱イオン水を加えて } 1 l \text { とする }\end{cases}
$$

ただし, 使用時 5.25 容のゲル用緩衝液と 1 容の電極用 緩衝液を混合し，これをさらに脱イオン水で 4 倍に希釈 し， $\mathrm{pH}$ を7.6 調整したもを用いる。

$$
\text { 電極用緩衝液 }\left\{\begin{array}{lc}
\text { 水酸化ナトリウム } & 1.2 \mathrm{~g} \\
\text { ホウ酸 } & 11.8 \mathrm{~g} \\
\text { 水を加えて } 1 l \text { とする. } \mathrm{pH} 8.2
\end{array}\right.
$$

これを $1 \mathrm{~N}$ の $\mathrm{NaOH}$ で $\mathrm{pH} 8.5$ に調整して使用す љ.

\section{2. ゲルの作製}

ゲル用緩衝液 $230 \mathrm{ml}$ と加水分解殿粉約 $30 \mathrm{~g}$ (殿粉の lot. により多少異なる) をナス型フラスコに入れ混合 乙，ガスバァーナー上で振りながら加熱し，均質なダル を作る、しばらく加熱すると次第に粘稠度が高くなる が，さらに強く振りながら加熱を続けるとゲルは透明に なりはじめ粘稠度もやや低くなる。そのときが加熱中止 の時期である。(あまり加熱をつづけるとゲルは液状と なり冷却してからの固化が悪い) 直ちに真空ポンプを用 いてフラスコを振りながらゲル中の気泡を除却する。は じめ細か心気泡が沢山でるが，吸引をつづけと大きな 気泡となるので，そのときに静かに常圧にもどす。この よらに脱気したゲルは熱いらちにゲル枠に流し込み, 表 面をアクリル平板で被い，重しをのせて固化するのを待 つ. 固化は室温で 2 時間位が適当である. 固化後アクリ ル板をとりはずし，クレラップシートでゲル上を被う。

\section{3. 試料の插入}

ゲルの陰極側から 5〜6 cm のところに試料插入の切 りこみを垂直につける。濾紙片に試料をたっぷり浸し， ピンセットを用いて切りこみに挿入する. 一枚のゲル板 に 10〜13 の試料が插入できる. 試料は, Tf 型, Am 型，Alp 型の検出のとさは原血清を用いるが，Alb型検 
出のときは血清を脱イオン水で 5 倍に希釈したものを用 いる. Hb 型は洗條血球を脱イオン水を加えた $2 \%$ 溶血 液を用いる。CA 型は洗條血球をそのま委凍結融解して 作った溶血血球泥を用いる。

\section{4. 電気泳動}

試料を插入したゲル板は，再びクレラップシートで被 い，再電極槽にブリッジで連結する。この場合，陰極ブ リッジは挿入点から約 $2 \mathrm{~cm}$ ぐらいのゲル上に叔く。泳 動定電圧とし, 初期電圧（初为の 30 分）は $10 \mathrm{~V} / \mathrm{cm}$ $(50 \mathrm{~mA} /$ ゲル)，最終電压は $14 \mathrm{~V} / \mathrm{cm}$ 位とする。泳動時 間は 3 時間前後で, 褐色のホウ酸バンドが試料挿入点か ら 9 10 cm に来たときに泳動を中止する。泳動を完了 したゲルは，ゲルカッターを用いて水平比 2 分する（各 $3 \mathrm{~mm}$ の愿さのゲルにする)。この操作は次のようにする とよい，まず挿入点から陰極側括よび陽極側の不要部分 のゲルを取り除き，泳動部分のゲル 約 $12 \mathrm{~cm}$ 位をゲル 枠を反転して静か㴟さ $3 \mathrm{~mm}$ のらちのある板上にの せる、ゲル上をガラス板で押觉，そのらちを基準にし て，ナイロン系または専用のゲルカッターで一気に水平 に切る。

\section{5. 染色および脱色}

$\mathrm{Tf}$ 型・Alb 型・ $\mathrm{Hb}$ 型・ $\mathrm{CA}$ 型: 蛋白染色液江水平 に半切したゲルを切った面を上にして数分間つづける. ついで染色液を取りのぞき脱色液にか党，20３0分間放 置する。ささらに脱色液を数回とりかえて，非染色部分の 脱色を行なう。

Am 型 : 半切にしたゲル (下側のものが良い)をがラ 又板上飞蛙さ，これを気密な湿润箱に扮さめ $37^{\circ} \mathrm{C} ， 1$ 晚 放置する。翌日これを取りだして，あらかじあ $4^{\circ} \mathrm{C} に$ 冷却してある 15\% アルコール溶液に浸し， $4^{\circ} \mathrm{C}$ 亿約 1 時間放置する。このような操作に㨟いて，アミラーゼバ ンドは次第に透明なバンドとしてみら礼るよらになる。 さらに，ゲルを水で軽く洗いガラス板上に扒いて室温に しばらく放置すると，アミラーゼバンドは一層はっきり 見られるようになる。

Alp 型：下記の液を使用前に調整し，これにゲルを浸 漬し $37^{\circ} \mathrm{C}$, 約 2 時間放置すると青褐色のバンドが発色し てくる.脱色液を加えて余分の染色液を除去する.

$$
\left\{\begin{array}{lr}
0.1 \mathrm{M} \text { バロナール緩衝液 ( } \mathrm{pH} \text { 8.6) } & 100 \mathrm{ml} \\
\text { シッジュウム } \alpha \text {-ナフチルホスイト } & 150 \mathrm{mg} \\
\text { ファスト・ブルーR Rソルト } & 100 \mathrm{mg} \\
10 \% \mathrm{MgCl} & 10 \text { 滴 }
\end{array}\right.
$$

$\mathrm{Cp}$ 型：下記の液をあらかじめ $37^{\circ} \mathrm{C}$ に温めて扣き，こ れにゲルを浸けて扣くと1時間後に赤褐色のバンドとし てみられるようになる。 $\mathrm{Cp}$ 型判定後,インキューベー ションを続行すると Am 型の検出もできる.

$$
\left\{\begin{array}{lr}
\text { ペラフェニレンジアミン } & 70 \mathrm{mg} \\
0.1 \mathrm{M} \text { 酶酸綏衝液 (pH } 5.7 \text { ) } & 100 \mathrm{ml}
\end{array}\right.
$$

酢酸綏衝液は次の組成である。

$$
\left\{\begin{array}{lc}
\text { 䣷酸ソーダ } & 20 \mathrm{~g} \\
\text { 水酭酸 } & 1.09 \mathrm{~m} l \\
\text { 脱イオン水を加えて } 1 l & \text { とする. } \mathrm{pH} 5.7
\end{array}\right.
$$

\section{6. 各蛋白質型の判定}

蛋白質型の判定のためには，赤血球抗原型の場合と異 なり，特殊な抗血清を必要とせず，また電気泳動像を行 なったパターンすなわら表現型から直ちに個体の遺伝子 型を決定できる利点がある。以下各蛋白質型にシステム の判定の仕方について述べる.

トランスフェリン型（ $\mathrm{T} f$ 型）：普通に認められるの は， A， $\mathrm{D}_{1} ， \mathrm{D}_{2}, \mathrm{E} の 4$ つの遺伝子の組合せからなる $\mathrm{A} / \mathrm{A}, \mathrm{A} / \mathrm{D}_{1}, \mathrm{~A} / \mathrm{D}_{2}, \mathrm{D}_{1} / \mathrm{D}_{1}, \mathrm{D}_{1} / \mathrm{D}_{2}, \mathrm{D}_{2} / \mathrm{D}_{2}, \mathrm{~A} / \mathrm{E}, \mathrm{D}_{1} /$ $\mathrm{E}_{1}, \mathrm{D}_{2} / \mathrm{E}, \mathrm{E} / \mathrm{E}$ の 10 型の遺伝子型で市る。写真 3 と図 3 亿示されるように，1つの遺伝子は 4 本1 組のバンド （泳動条件によっては 3 本になる）を支配し，A遗伝子 $(+)$

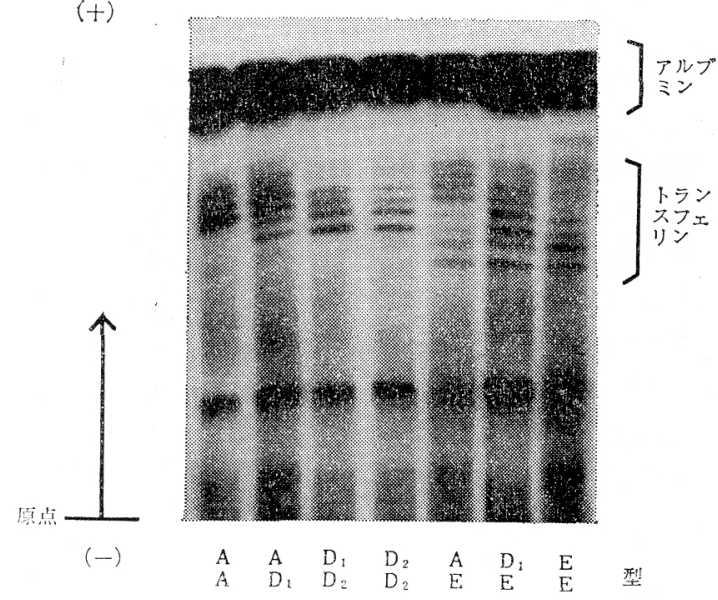

写真 3 牛血清のトランスフェリン型

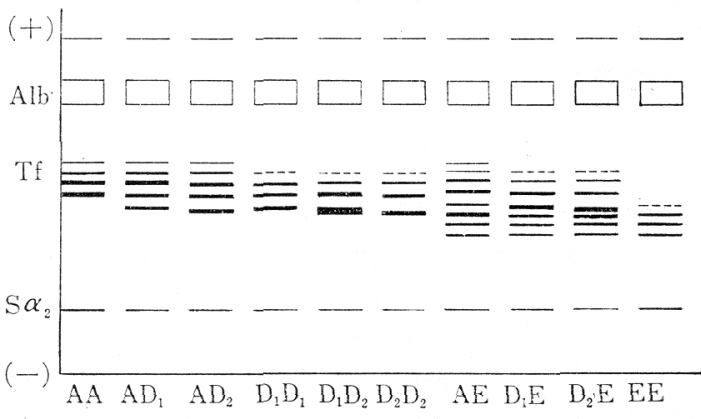

図2 牛血清のトランスフェリン型

は易動度の最む早い 4 本 1 組のバンドをあらわし，次い で易動度の順に $\mathrm{D}_{1} ， \mathrm{D}_{2} ， \mathrm{E}$ で㐫る。 $\mathrm{D}_{1}$ と $\mathrm{D}_{2}$ の易動 度の差は極めてわずかで㐫る。 $\mathrm{A} / \mathrm{A}, \mathrm{D}_{1} / \mathrm{D}_{1}, \mathrm{D}_{2} / \mathrm{D}_{2}, \mathrm{E} / \mathrm{E}$ のホモ型のものは 4 本のバンドであるが， $\mathrm{A} / \mathrm{D}_{1}$ のよう 
技術

なへテロ型のものの泳動像は $\mathrm{A} / \mathrm{A}$ 型と $\mathrm{D}_{1} / \mathrm{D}_{1}$ 型をち ょらど重ね合わせたよらに 6 本のバンドが認められる. $\mathrm{A} / \mathrm{E}$ 型では 8 本のバンドがみられる。 ホルスタイン種 では, $\mathrm{A}, \mathrm{D}_{1}, \mathrm{D}_{2}, \mathrm{E} の 4$ 遺伝子であるが, 台湾黄牛や 和牛ではEバンドより易動度がさらに遅いXバンドが極 めて稀にみられるときがある。

アルブミン型 (Alb 型)：2つの対立遺伝子 $\mathrm{Alb}^{\mathrm{A}}$ と $\mathrm{Alb}^{\mathrm{B}}$ によって支配される 3 型がある(図 2). $\mathrm{Alb}^{\mathrm{B}}$ 遺伝 子はゼビウ系牛に多いが, ヨーロッパ系牛にはほとんど みられない。 あか牛には $\mathrm{Alb}^{\mathrm{B}}$ が数\%存在する。

アルカリ性ホスファターゼ型 (Alp 型) : 血清中のア ルカリ性ホスファターゼは, 各臟器起源のものの集った ものであるので, そのアイソザイムパターンにはかなり の変異がみられる. しかし牛の場合, 大別すると 2 型に 分けられる. すなわち, 易動度の最も早いAバンドの有 無によってA型とO型に分けられ, その性質は遺伝的で あり, AlpA は Alp に対して優性である.Aバンドは小 腸起源のものと考えられている，興味あることはAバン ドを有する個体の血清中のアルカリ性ホスファターゼ活 性値は高く, また血清中の J 物質の出現と全く負の関係 にあることが知られている。

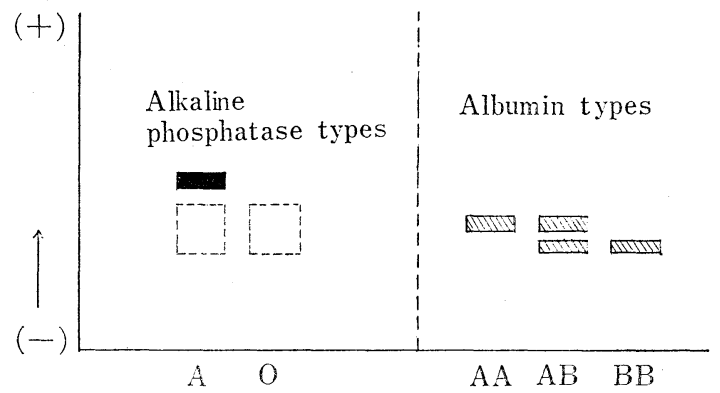

図 3 牛血清のアルカリ性ホスファターゼ型と アルブミン型

アミラーゼ型 (Am 型) : Tf 型の泳動を行なった場 合の半分のゲルまたは $\mathrm{Cp}$ 型判定後のゲルを用いて判定 できる,アミラーゼ型は 3 つの対立遺伝子 $\mathrm{Am}^{\mathrm{A}}, \mathrm{Am}^{\mathrm{B}}$, $\mathrm{Am}^{\mathrm{C}}$ によって支配されていることが知られているが, Aバンドと Bバンドの易動度の差は極めてわずかなので 区別が困難である，そこで通常はBとCのみによって 3 型に分類している(図 4), 牛血清のアミラーゼ型はこの

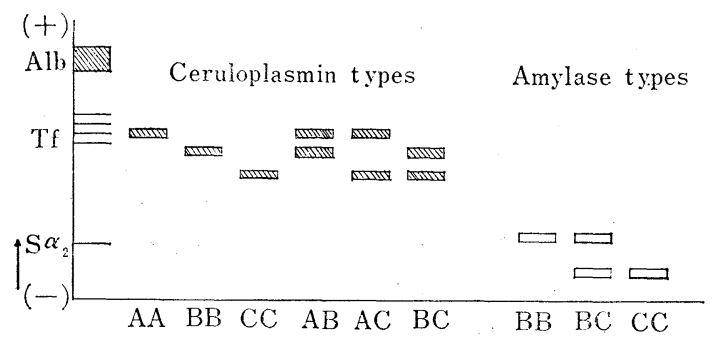

図 4 牛血清のセルロプラミン型とアミラーゼ型
韮座

他に原点付近に見られる Am II 型システムがあるが, 判 定がむずかしいので通常の検查には用いられていない，

セルロプラスミン型 (Cp 型) : 3つの対立遺伝子 $\mathrm{Cp}^{\mathrm{A}}, \mathrm{Cp}^{\mathrm{B}}, \mathrm{Cp}^{\mathrm{C}}$ によって支配され，6型に分類される (図 4)，Aバンドの易動度と活性は安定しているが， B とCバンドは血清を凍結融解したり長期保存すると不安 定となるので注意を要する，

血球カーボニック・アンヒドラーゼ型(GA 型) : この 型は本来エステラーゼ発色による第 2 域にみられる遺伝 的変異であるが, 通常は蛋白染色によって判定されてい る.

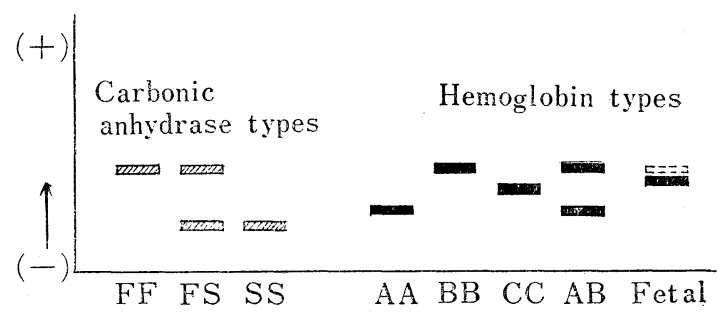

図 5 牛血球のカーボニック・アンヒドラーゼ 型とへモグロビン型

図 5 に示したよらに，2つの対立遺伝子 $\mathrm{CA}^{\mathrm{F}}$ とCAS に支配される 3 型がある, 大抵の品種に拉いて $\mathrm{CA}^{\mathrm{S}}$ か $\mathrm{CA}^{\mathrm{F}}$ より多く，また活性も $\mathrm{CA}^{\mathrm{S}}$ の方が高いことが知 られている,

ヘモグロビン型 (Hb 型) : 3 つの対立遺伝子 $\mathrm{Hb}^{\mathrm{A}}$, $\mathrm{Hb}^{\mathrm{B}}, \mathrm{Hb}^{\mathrm{C}}$ があり, $\mathrm{Hb}^{\mathrm{C}}$ はインド系牛に見出されてい る, 牛のへモグロビン型の記号は通常の場合と異なり, 易 動度の順にB，C，Aであることに注意する必要がある. これは，はじめAのみが見出されその後にB，Cなどが 見出されたからである, 大部分のヨーロッパ采では $\mathrm{Hb}^{\mathrm{A}}$ のみであるが, ジャージー, サウスデボン, ガンジーお よび和牛には $\mathrm{Hb}^{\mathrm{B}}$ が見出されている.（つづく）

日獣製作カラースライド

\section{牛 の 乳房炎}

企画日本獣医師会 指導

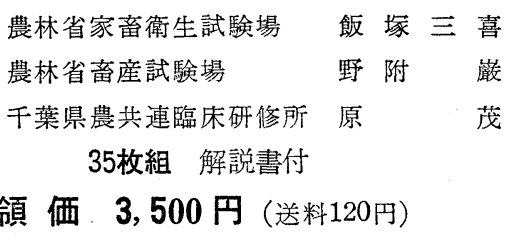

（申达）社団法人 日本 獣医師 会 東京都港区南青山 7-2-10（干 107） 電話 東京 (03) 406-5271 (代表) 郵便振替口座 東京 6-68304 番 